\title{
Euphemism as a Mechanism of the Internal Workings of the Politically Correct Language
}

By Reinaldo César Zanardi \& Marcelo Silveira Abstract- As a social phenomenon, the politically correct is very recent and operate in the perspective of defending the individual rights of marginalized segments. In this context, the object of this study refers to the politically correct language (PCL), which can be defined as the process of substitution of stigmatized variants for others that are considered positive or neutral. Thus, the purpose of this paper is to present the euphemism as an internal mechanism of functioning of the PCL, justified by the need to reflect on prestige variants in three semantic fields: disability, blackness and homosexuality. The corpus covers online collection of the newspaper Folha de S. Paulo, an important Brazilian journal. As a result, euphemism in PCL: i) softens pejorative meanings, ii) inscribe new meanings in variants in use, iii) is also associated with technical variants in areas such as health and law, and finally iv) can also be exaggerated, contributing to other negative meanings.

Keywords: euphemism, politically correct language, disability, blackness, homosexuality.

GJHSS-G Classification: FOR Code: 200399

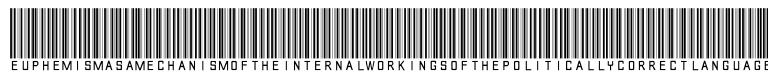

Strictly as per the compliance and regulations of:

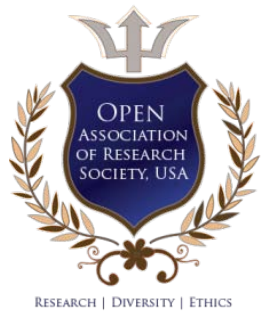

(C) 2019. Reinaldo César Zanardi \& Marcelo Silveira. This is a research/review paper, distributed under the terms of the Creative Commons Attribution-Noncommercial 3.0 Unported License http://creativecommons.org/licenses/by-nc/3.0/), permitting all noncommercial use, distribution, and reproduction in any medium, provided the original work is properly cited. 


\title{
Euphemism as a Mechanism of the Internal Workings of the Politically Correct Language
}

\author{
Reinaldo César Zanardi ${ }^{\alpha} \&$ Marcelo Silveira ${ }^{\sigma}$
}

Abstract- As a social phenomenon, the politically correct is very recent and operate in the perspective of defending the individual rights of marginalized segments. In this context, the object of this study refers to the politically correct language (PCL), which can be defined as the process of substitution of stigmatized variants for others that are considered positive or neutral. Thus, the purpose of this paper is to present the euphemism as an internal mechanism of functioning of the $P C L$, justified by the need to reflect on prestige variants in three semantic fields: disability, blackness and homosexuality. The corpus covers online collection of the newspaper Folha de S. Paulo, an important Brazilian journal. As a result, euphemism in PCL: i) softens pejorative meanings, ii) inscribe new meanings in variants in use, iii) is also associated with technical variants in areas such as health and law, and finally iv) can also be exaggerated, contributing to other negative meanings.

Keywords: euphemism, politically correct language, disability, blackness, homosexuality.

\section{INTRODUCTION}

T he language, taken as a dialogic process, reveals interaction as an important precondition because through it involvement of partners with the text happens, be it written or spoken, each one with specific features. One of the fundamental characteristics of the interaction is, therefore, reciprocity, which creates common contexts and produces, in practice, meanings from the language and its structure.

Barthes (2000), in this line of reasoning, emphasizes that the language is, practically - at the same time -, a social institution and a system of values. The language, while social institution, is a collective agreement, the social part, in which an individual, alone, cannot modify it. As a system of values, a language "is made of a certain number of elements, each one is at the same time the equivalent of a given quantity of things and a term of a larger function, in which are found, in a differential order, other correlative values [...]" (Barthes, 1986, p. 14).

In a social perspective of language, Monteiro (2000, p. 16) emphasizes that its role of "establishing social contacts and the social role that it plays to convey information about the speaker, both constitute a proof

Author a: Phd in Language Studies (UEL), journalist, professor of journalism at UEL. e-mail: rczanardi@gmail.com

Author o: Phd in Language and Literatture - Philology and Portuguese Language. Argumentation and Rhetoric (USP), professor of Linguistics at UEL. e-mail: celosilveira@gmail.com that there is an intimate relationship between language and society".

Lefebvre (1966) corroborates this reasoning, for whom the language should not be separated from the society that originates it. "How to understand the Greek language without the Greek society, the Latin without Rome, and romanity, and latinity?" (Lefebvre, 1966, p. 28).

To Lefebvre (1966, p. 35), "the language can no longer conceive itself as a bag of words", nor can it be centered in the "concept of language-repertoire that is based on simplistic thesis that the whole world is ordered, before the vision the men have". This means that the world is not structured in stages and that people use language (as one of these stages have already structured) to be something in society.

$[\ldots]$ the existence of language has nothing to do with hypothetical or speculative. It is social and practice. If, on the one hand, its internal structure allows you to better define the rationality, on the other hand, it has a reality. It is the real human, or at least an important part and perhaps characteristic (or essential) of such a reality (Lefebvre, 1966, p. 37).

This research is in the social perspective of language-speech relation and its objective is to present the euphemism as an internal mechanism of functioning of the politically correct language (PCL). This study is justified by the need to reflect on variants of prestige in three semantic fields: disability, blackness and homosexuality.

The corpus of this study considers the online acquis from the newspaper Folha de S.Paulo (São Paulo Newspaper), very important in Brazil. The Group Folha began his business career in 1921 with the Night News. In 1925, the morning edition of the newspaper was created: the Morning News. In 1949, a new daily newspaper was created: Afternoon News. In January 1960, the three titles were incorporated into one, becoming Folha de S.Paulo.

The newspaper Folha de S.Paulo, as a corpus, is justified for (i) its importance in Brazilian scenario, (ii) having one of the largest circulations among the printed newspapers of the country (the largest circulation in 2017, according to the Circulation Verification Institute (CVI), (iii) the reciprocal linguistic influence between newspaper and society. When the newspaper uses an official variant, it encourages society to use it, and when society consolidates a variant, the newspaper uses it. 


\section{The Politically Correct}

The politically correct is a recent social phenomenon whose origin can be dated, in Brazil, from the 1990s. While movement, this behavior has received foreign influence, mainly in the United States. It is in the context of the defense of civil rights that this phenomenon should be understood. The struggle for human rights in the United States was strengthened by ethnic prejudice and racial segregation present in NorthAmerican society.

As a result of claims, affirmative policies that aim to create opportunities especially for blacks in various sectors arise in the United States. These actions aim to correct racial inequalities, characteristic strengthened over the centuries, including the enslavement of African communities worldwide.

There is no consensus among researchers about the origin of the politically correct while behavior, but there are important clues in the few researches about the theme. The first record of the term politically correct is not associated with the current understanding. The term was used in 1793, in a decision of the Court of the USA in the case Chrisholm X Georgia. The conclusion comes from researcher Stodůlková (2007, p. 11), who that the term was used opinatedly without reference to its meaning in the context of the decision.

According to the author, even if the concept of politically correct has been consolidated more recently, some hypotheses refer the roots of the term, as it is designed in the present day, to the theorist and Russian politician Vladimir Lenin.

The establishment of PC is here seen as a decisive ideological criterion of Marxism-Leninism which was applied to a written discourse, as well as the spoken one. The criterion enforced restrictions on verbal spontaneity and skepticism and lead to the parties attempts to police free thinking. The character of such ideology is sometimes mentioned by critics of the PC in last two decades as resembling PC principles (Stodůlková, 2007, p. 11).

Stodulková (2007) affirms that there is another argument for believing that the Marxist-Leninist stream is regarded as one of the pillars of the politically correct. It is the concept of Lenin's politicheskaya pravil'nost, in 1917. From the Russian, the author translates to English as political correctness. "Lenin's concept is an explicit reference to right/wrong, correct/incorrect from a political point of view" (Stodůlková, 2007, p. 12).

If, on the one hand, the politically correct, in its origin, is associated with the behavior, i.e., with the attitude while action, understood in a political dimension, on the other hand, it is important to note that this mechanism interferes directly in the language, after all the language in use is not disassociated from the behavior, be it individual, be it collective. Through language people express ideas, manifest, communicate, propagate ideologies, exchange experiences, finally talk and interact with each other.

This proposal is supported by Lenin's concept politicheskaya pravil'nost, therefore it is a controversial issue that raises unconditional defense and aggressive attack.

The advocates of this modality believe that replacing the expressions would contribute to attenuate prejudice, whatever order (social class and origin, race or ethnicity, gender or sexual orientation, age, among others) and to promote respect and human rights. Now the opponents of the modality ensure that PCL restricts the ability of expression and promotes censorship to try to regulate linguistic variants of the universe of speakers.

In language development, it is worth highlighting the role of linguistic belief as a means of motivation for the use of variants which determine an attitude interfering in linguistic behavior. This is a mental procedure that is not necessarily conscious. This means that, if a speaker believes that a particular variant harms his interlocutor, he seeks, in its linguistic repertoire, another way tending to soften, smooth out the negative direction already consolidated in the previous variant.

On that subject, it is worth highlighting the role of euphemism in the production of politically correct variant. More than just a figure of speech, this feature seems to be a structuring element of variants of this modality. Moreno-Fernandez (2009, p. 197) does not deal with politically correct, but recognizes that euphemism has the role to dispel the unpleasant and what offends people.

According to the author, the causes of the euphemism are verified in various circumstances, as more formal or informal style; respectful treatment to other people; fear, admiration and respect; and to smooth out insults. Not by coincidence, the figure of speech euphemism is regarded as "any softened or understated way of expressing certain facts or ideas whose rawness can hurt" (Dubois, Giacomo, Guespin, Marcellesi, Marcellesi \& Mevel, 2006).

The politically correct is not a system or rule, nor law to be fulfilled from legal devices. It is more for a rational and aware proposal of behaviors including linguistic ones that affect mainly vulnerable social groups such as homosexuals, blacks, persons with disabilities, indigenous people, children and teens, people experiencing homelessness, among others.

\section{ili. Variants for Person With Disabilities}

Deficient and disabled came to be, over time, in Brazilian Portuguese, stigmatized variants and their linguistic usage is not recommended. In the first case, it is considered a stigmatized variant by government agencies for being a "generalizing, inadequate 
treatment [...] Having a disability does not make a person invalid or incapable" (Queiroz, 2004, p. 14). Already in the second case, the disabled (literally bearer of deficiency in Portuguese) presents stigma by PCL because it treats the disability not as characteristic of the individual, but as something portable. There is no portability for the deficiency.

In this sense, the recommended by PCL is person with disabilities. One can note that the use of person humanizes variant because it leads to someone with feelings and emotions, life experiences, desires, dreams and frustrations. This means to say that the variant meaning core is the person and not their disability, which can be considered as any other characteristic inherent to the human being.

Even in negative approaches, such as the physical violence, the variant person with disabilities presents positive valency ${ }^{1}$, i.e., the use of this form has prestigious character. An example can be found in the report "A psychologist with paralysis says she suffers violence at home and outside home," 11/11/2013. The report discusses the history of a psychologist, Fatima (fictitious name), 56 years old, which suffers from various types of violence at home and outside home (Excerpt 1). Her physical disability is the result of an aneurysm.

\section{Excerpt 1}

"As I was leaving for the public space, I was becoming more exposed to aggression, both caused by physical barriers and attitude barriers of people," says psychologist. [...] "Today I note that any reaction of a person with disabilities becomes, for others, synonymous with madness," says Fatima (Marques, 2013a). ${ }^{2}$

The linguistic form person is used in various circumstances to designate other deficiencies. The variant deaf person can be regarded as a euphemism for the deaf, besides deaf is a variant form of prestige, and not stigmatized. The term deaf is marked as correct by Andi (2003) and Queiroz (2004).

One can notice euphemism in the variant deaf person in another example. "According to the IBGE, the city of São Paulo has 516 thousand inhabitants with hearing disabilities, which involves deaf people who speak Libras [Brazilian Sign Language], deaf oralized (who make lip-reading), people with hearing difficulties [...]" (Marques, 2016).

If deaf is a variant of prestige advocated by the deaf community, why use a euphemism, as recorded in deaf people? Two causes can explain. Firstly, the form person from the variant person with disabilities influences the formation of new terms. Secondly, many do not know that deaf is considered politically correct and call for the euphemism to overreact. This way you can even have a pejorative bias.

The PCL is not a homogeneous or linear social phenomenon. It is fragmented and sometimes confused when one abuses the euphemism usage. In an attempt to establish the status, the exaggeration exchanging one term for another can lead to stigma, becoming more derogatory than the original variant.

Initially, the variant person with deafness might be understood as a euphemistic derogatory form to deaf. However, it is not what happens, since its context establishes levels for deafness, i.e., it highlights the hearing deficiency in its different degrees.

In a report on developments in a trade fair for people with disabilities, the text of a photography description informs that a "device allows people with mild and moderate deafness to spend four months without worrying about the equipment, which is inserted in the inner part of the ear" (Marques, 2013b).

When it comes to disability, the form person from person with disabilities influences the formation of other variants. The report "Fernando de Noronha makes changes to be accessible to tourists with disabilities, 06/02/2013," registers six occurrences for quadriplegic, which would be equivalent to deficient, since the meaning of the variant is consolidated by the deficiency. The report records, once, the occurrence of quadriplegic people (Excerpt 2).

\section{Excerpt 2}

"When I entered that wonderful sea, the impression was that my body took on another shape and that I was someone else, with much more movement," says the Swiss Michael Peneveyle, 46. He is the director of the NGO Wheels of Freedom and one of the first quadriplegic people with restricted movements below the neck to swim in the waters of Sueste beach, in Fernando de Noronha (Pernambuco, Brazil), the quieter side of the archipelago and which is now fully accessible (Marques, 2013c).

If, on the one hand, quadriplegic person is a variant to refer to a person with permanent disability, since quadriplegia has no cure, on the other hand, there are situations in which the use of the form person can also refer to situations in which the disability is temporary. In Excerpt 3, people in wheel chairs suggests that this is not necessarily a wheelchair user, someone with permanent disability, but a situation of reduced mobility, as an old-aged person or someone recovering from surgical procedure.

\section{Excerpt 3}

There, in the exclusive garage of secretary Fernando Grella Vieira and other members of the security summit, "preferential entry" for people in wheel chairs has been installed. Around the building, the sidewalks are narrow and do not have tactile floor yet, which guides the blind to entries (Woodville, 2014).

Once more, the variant person pulls the sense for itself, humanizing the condition of those who have movements restriction, leaving in the background the sense of permanent or temporary disability. One can, also, note that the use of the form person is associated 
to its own variant person with disabilities; regardless of its condition, it is a person, a person who has desires, dreams and projects.

\section{Variants for Black}

The variant black, in Brazilian Portuguese, is a categorical variant and of prestige. It occurs in different situations, being used by militants of the black movement and out of militancy. It is recorded in facts and events both positive and negative, in the text of the reporter, in the headline produced by the editor and the declarations of the interviewees.

As a prestigious variant for black, let us take some headlines as examples: a) "Blacks occupy only $18 \%$ of elite positions, according to survey," 06/08/2015; b) "USP students protest in favor of quotas for blacks in universities," 04/30/2015; c) "Police postpones reconstitution of assault on black security guard in Carrefour from Osasco (SP)," 07/28/2010. The examples show that it is a prestigious variant, even if the context of occurrence has a negative valence because of the origin of the fact or event, such as the death of a black security guard.

If, on the one hand, the black variant is consolidated as a prestige variant of the PCL, on the other, it ends up being used as a stigmatized form to offend men or women. This shift of meaning can be seen in the report "Market customer in SP is called 'peripheral black' in row fight," 12/07/2017 (Excerpt 4).

\section{Excerpt 4}

Tempers were still high when the man shouted, "you peripheral black, get out of here," among other curses. The retiree denies racial injury but admits aggression. [...] "I couldn't stand it and I punched him in the face. Unfortunately, I lost my mind," said the retiree. "But I didn't even call him black, because he is not black. He is brown. I'm not a racist. My partner, with whom I lived eight years, is black," he says (Zylberkan, 2017).

The euphemistic uses for the black variant are also detected associated with the form person. In Excerpt 5, the report addresses murder statistics when comparing black's and white's reality in Brazil.

\section{Excerpt 5}

The possibility of a black person being murdered in Brazil is $87 \%$ higher than that of a white person. The datum is revealed in a survey by professors Gláucio Soares and Doriam Borges, from Cândido Mendes University, Rio de Janeiro (Monken, 2004).

The exaggerated use of euphemism in the context of blackness is evidenced by two very significant examples: someone with black complexion and a blackskinned person. These forms explicitly present the euphemism's mechanism for softening the meanings of the word itself. The report "Precinct chief says investigations into Eliza's Disappearance are advanced," 07/16/2010, refers to the case of goalkeeper Bruno, accused of killing Eliza Samudio.
In Excerpt 6, the precinct chief investigating the disappearance, in direct quotation, uses the variant someone with black complexion.

\section{Excerpt 6}

"Asked about the divergences in the physical characteristics of the person he identified as the executor, he said that the person he referred to as Neném would be someone with black complexion, because he wanted to 'flummox' the press, because he knew the facts would be published. The fear of the performer frightens him and leads him back to a real horror movie," said the precinct chief [Ana Maria dos Santos] (Folha Online, 2010).

Excerpt 7 addresses the variant black-skinned person whose context is an interview with the maid Simone Andr Diniz. She was a victim of racial discrimination in responding to a job posting. The variant presents senses softened by the action of the euphemism.

\section{Excerpt 7}

Folha - When you called, did you think you could change the opinion of the ad author?

Simone - I thought it could have been a mistake. But that was not it. They really didn't want to. They didn't want a black-skinned person at all (Penteado, 2006).

In the field of blackness, there is an interesting linguistic phenomenon. The diminutive can be a linguistically euphemistic resource for bringing the interlocutors closer and even revealing a loving variant among friends, so it is considered prestigious in Brazil, besides our ipsis litteris translations shows the opposite: the use of the diminutive in different linguistic variants, such as blackie, niggerling and darky, respectively pretinho, neguinho and escurinho, since it seems there is no corresponding form in English: loving and euphemistic, depending on the context. However, analysis of the context of occurrence reveals stigma because its use is in the context of prejudice or discrimination, as in Excerpt 8, which demonstrates the use of niggerling people to offend.

\section{Excerpt 8}

According to Luiz Guilherme Carvalho, partner of Belini Bakery, the woman complained about the amount paid for the snack (about R\$ 8 Reais, around \$2) and, when approached by the manager, black, triggered verbal aggressions. "She started screaming 'you are a lot of black thief, niggerling'. Everyone in the store has stopped. Our nutrition technique, also black, approached the client to try to calm her down, and the client said 'another black woman, naughty, wanting to rob me'," said the bakery partner (Folha Online, 2013).

The form blacky also appears in a pejorative context. In the report "Professor accused of racism by undergraduate accepts settlement in process," $6 / 1 / 2005$, one undergraduate reports the prejudice suffered in the classroom when the teacher used prejudiced forms. "According to the student, in June 
2004, during a class, the teacher used racist expressions like [...] 'little black dress', besides telling a joke" (Corrêa, 2005). In Portuguese, there are two main ways of using diminutive: by adding little before the noun or by adding suffix -inho.

The form darky does not consist of a variation for ethnicity and is not even related to the color of the skin as black and white. Football is in Brazil a means of social ascension for many young black people. This is the case of the soccer player Alex Barbosa de Azevedo Terra. In December 2001, Alex scored for Rio de Janeiro the first goal of his career. It was against Corinthians. Despite saying that he perceives racism in the labor market, the player stated that he never felt discriminated against by players (Excerpt 9).

\section{Excerpt 9}

Alex said he is "following up" on blacks' claims for better living conditions. [...] He says he has never felt discriminated against by other athletes and considers "affectionate" nicknames such as "darky". "In soccer we fight for equal. Just see that Pelé is black" (Folha Online, 2002a).

Even if the player does not feel discriminated against as being called darky, it does not mean that the use of this form is not prejudiced. Again, it is the context in use that will determine the prestige or stigma of a linguistic variant.

\section{Variants for HomoseXual}

Like disability and blackness, the field of homosexuality has also consolidated the use of the form people in prestige variants, for example, in homosexual people and LGBT people (Lesbian, Gay, Bisexual, Transgender). This corpus repeats the main meaning in the human being and not in sexuality, whatever the sexual orientation. This movement reaffirms the role of euphemism in the functioning of the PCL. The combination of the word homosexual with other lexical items softens the meaning for homosexuality.

In the report "'Sexual reorientation' in therapies has new judge approval; council will appeal," 12/15/2017, the decision of a magistrate who authorized psychologists to "serve gays and lesbians who seek change in sexual orientation in cases defined as 'egodistonic sexual orientation'" is discussed (Cancian, 2017). The Federal Council of Psychology spoke during the report, differing from the judge's decision (Excerpt 10).

\section{Excerpt 10}

It is not a question of denying the suffering to which homosexual people are affected by LGBT phobia, however understanding that suffering is not in sexual orientations per se, but related to social conditions that give pejorative meaning to their expressions and experiences (Cancian, 2017).

The occurrence of LGBT people follows the same pattern as the euphemism found in other variants.
The meaning in the use of people humanizes the linguistic form, highlighting the dignity of the human being (Excerpt 11).

\section{Excerpt 11}

This year, from January to June, according to the NGO, there were 16 cases of murder of LGBT people in Bahia and 123 in Brazil. Last year, GGB reported 319 deaths from homophobia or a hate crime every 27 hours. Of this total, 33 (10.3\%) were in Bahia, which was only behind São Paulo, with 55 (17\%) (Guimarães, 2016).

Still with emphasis on people, the variant samesex people reveals two important aspects: i) the humanization of the form people and ii) the erasure of homosexuality with the withdrawal of the form homosexual. The variant inscribes new meanings in use. "Authorization for same-sex civil marriages is driving Brazilian courts astray. Decisions have been taken in different ways in each state of the country" (Brisolla, 2012).

In the field of homosexuality, an interesting linguistic phenomenon occurs with the replacement of the form person by woman and man, in this case homosexual women and homosexual men. The replacement of the generic term person occurs because of gender (female and male) (Excerpts 12 and 13).

\section{Excerpt 12}

Two homosexual women opened a new evangelical church, the Community Cidade de Refúgio (City of Refuge), in downtown São Paulo. [...] Located on São João Avenue, in the Santa Cecília neighborhood, the new church gathered 300 people on the first day (Folha Online, 2011).

\section{Excerpt 13}

The court has authorized a couple of homosexual men to register a child as a daughter. The men's names, who live in Catanduva (385 km from SP), appear as parents of the girl on the birth certificate (Baptista, 2006).

The euphemism, as a mechanism of operation of the PCL, can also be verified in variants of the technical language. The highlight is the language of the legal field, within the scope of the law operators. The form homoaffective is widely used to refer to same-sex social rights, such as marriage, adoption, health insurance, death benefits, and inheritance. The term homoaffective, of affective-conjugal character, was coined by the judge of the state of Rio Grande do Sul Maria Berenice Dias, in her court decisions. Since then, the variant has been used in the legal universe (Excerpt 14).

\section{Excerpt 14}

The rapporteur of the case stated in his decision that "it is reasonable to claim that it would be important [...] to prevent children from the necessary conviviality and care in the first months of life, on the grounds of a lack of constitutional or legal provision for the granting of a 
license in the case of adoption or custody granted to a homosexual couple" (Folha Online, 2012).

In addition to the field of Law, health also bets on euphemism to use politically correct variants. One variant stands out in the context of health professionals: men who have sex with men. The meaning used in this form is tied to the man who has sex with another man, but he does not define himself as homosexual. In Brazilian culture, men who make the role of "active" are commonly not labelled themselves homosexual. This label is reserved for the man who plays the role of "passive". The Excerpt 15 show part of the article dealing with AIDS cases among homosexuals and heterosexuals.

\section{Excerpt 15}

In 2001,30.4\% occurred among men who have sex with men and $27.4 \%$ among heterosexuals. In the country, until $2000,42.5 \%$ of the records were transmitted among heterosexuals and 35\% among men who have sex with men, according to the STD/AIDS National Coordination (Leite, 2003).

The same meaning path is made when it comes to the homosexual woman. "The fact that doctors are not sensitive should not make the visit unfeasible [...]. Women who have sex with women should make their sexual orientation clear and demand appropriate care" (Folha Online, 2002b).

\section{Vi. Conclusion}

Politically correct language exists, and its linguistic variants are consolidated and in use, be it in people's everyday speech or in journalistic language and media. This process is not homogeneous, and the prestige of the variants changes according to the subjects and social actors.

In this context, euphemism reveals itself as the main mechanism of functioning of politically correct language, softening meanings considered negative and even resignifying linguistic forms. However, it is the linguistic use that determines the prestige of a variant in its production context.

It is worth noting that euphemism can also be stigmatizing, since the exaggeration of this mechanism even associated with the diminutive contributes to derogatory senses instead of softening the pejorative burden.

Finally, the use of many politically correct variants is associated with technical characteristics of the segment that integrates, for example, legal and health fields. This reveals that these segments seek linguistic variants that portray their audiences in order to respect them in their characteristics.

Politically correct language is not a law to be followed. However, this modality is consolidated and, although not established by legal frameworks, can be considered a linguistic norm in language-society relation. After all, the language variants in use, whether politically correct or not, reveal a lot about who uses them.

\section{References Références Referencias}

1. ANDI. (2003) Mídia e deficiência. Brasília: Andi/Fundação Banco do Brasil.

2. BAPTISTA, R. (2006, Nov. 23) Justiça autoriza casal gay a adotar criana no interior de SP. Folha, Available at: http://www1.folha.uol.com.br/folha/ cotidiano/ult95u128520.shtml.

3. BARTHES, R. (1986). Elements of semiology 11. Print.). Translated by Jonathan Cape Ltd. New York: Hill and Wang.

4. BRENHA, H. (2014, Jun. 28). Em delegacia para deficientes de SP, cadeirante entra pelos fundos. Folha. Available at: https://www1.folha.uol.com.br/ cotidiano/2014/06/1477884-em-delegacia-para-defi cientes-de-sp-cadeirante-entra-pelos-fundos.shtml.

5. BRISOLLA, F. (2012, Jun. 3). Casamento de homossexuais divide os tribunais brasileiros. Folha. Available at: http://www1.folha.uol.com.br/cotidiano /2012/06/1099673-casamento-de-homossexuaisdivide-os-tribunais-brasileiros.shtml.

6. CANCIAN, N. (2017, Dec. 15); 'Reorientação sexual' em terapias tem novo aval de juiz; conselho irá recorrer. Folha. Available at: http://www1.folha.uol. com.br/cotidiano/2017/12/1943795-reorientacaosexual-em-terapias-tem-novo-aval-de-juiz-conselhoira-recorrer.shtml.

7. CORRA, H. (2005, Jun. 1). Professor acusado de racismo por universitrio aceita acordo em processo. Folha. Available at: http://www1.folha.uol.com.br/ folha/cotidiano/ult95u109614.shtml.

8. DUBOIS, J, Giacomo, M., Guespin, L., Marcellesi, C., Marcellesi, J.-B., \& Mevel, J.-P. (2006). Dicionário de lingüística. Translated to Portuguese by Frederico Pessoa de Barros et al. São Paulo: Cultrix.

9. FOLHA ONLINE. (2002a, Jan. 6). Nunca vejo aeromoça negra, diz jogador de futebol. Folha. Available at: https://www1.folha.uol.com.br/folha/ cotidiano/ult95u43403.shtml.

10. FOLHA ONLINE. (2002b, Jun. 1). Debate alertou sobre risco saúde para homossexuais. Folha. Available at: https://www1.folha.uol.com.br/folha/ cotidiano/ult95u52107.shtml.

11. FOLHA ONLINE. (2010, Jul. 16). Delegado diz que investigações sobre desaparecimento de Eliza estão avançadas. Folha. Available at: http://www1. folha.uol.com.br/cotidiano/2010/07/768321delegado-diz-que-investigacoes-sobredesaparecimento-de-eliza-estao-avancadas.shtml.

12. FOLHA ONLINE. (2011, Jun. 16). Mulheres homossexuais criam igreja evangélica no centro de SP. Folha. Available at: https://www1.folha.uol.com. 
br/cotidiano/930854-mulheres-homossexuais-criamigreja-evangelica-no-centro-de-sp.shtml.

13. FOLHA ONLINE. (2012, Nov. 27). Servidor público homossexual consegue licença-maternidade em MS. Folha. Available at: https://www1.folha.uol. com.br/cotidiano/1191998-servidor-publico-homo ssexual-consegue-licenca-maternidade-em-ms. shtml.

14. FOLHA ONLINE. (2013, Jun. 3). Cliente presa após chamar gerente de padaria em Brasília de 'neguinho'. Folha. Available at: https://www1.folha. uol.com.br/cotidiano/2013/06/1289224-cliente-epresa-apos-chamar-gerente-negro-de-padaria-embrasilia.shtml.

15. GUIMARÃES, T. (2016, Jun. 15). Docentes gays carbonizados em carro levam cidade do sertão baiano s ruas. Folha. Available at: https://www1. folha.uol.com.br/cotidiano/2016/06/1781884-doce ntes-gays-carbonizados-em-carro-levam-cidadedo-sertao-baiano-as-ruas.shtml.

16. LEFEBVRE, H. (1966). A linguagem e a sociedade. Translated to Portuguese by José António Machado Lisbon: Ulissia.

17. LEITE, F. (2003, Nov. 29). Casos de Aids empatam entre gays e heteros. Folha. Available at: http://www1.folha.uol.com.br/folha/cotidiano/ult95u8 6407.shtml.

18. MARQUES, J. (2013, Nov. 11). Psicóloga com paralisia diz sofrer violência dentro e fora de sua casa. Folha. Available at: https://www1.folha.uol. com.br/cotidiano/2013/11/1369570-psicologa-comparalisia-diz-sofrer-violencia-dentro-e-fora-de-suacasa.shtml.

19. MARQUES, J. (2013b, Apr. 19). Feira para pessoas com deficiência traz cadeira de rodas 'off-road'. Folha. Available at: http://www1.folha.uol.com.br/ cotidiano/2013/04/1265220-feira-para-pessoas-com -deficiencia-traz-cadeira-de-rodas-off-road. shtml.

20. MARQUES, J. (2013c, Feb. 6). Fernando de Noronha faz mudanças para ser acessível a turistas com deficiência. Folha. Available at: http://www1. folha.uol.com.br/cotidiano/2013/02/1226608-fern ando-de-noronha-faz-mudancas-para-ser-acessivel -a-turistas-com-deficiencia.shtml.

21. MARQUES, J. (2016, Feb. 3). Intérpretes de surdos auxiliam de partos a formaturas em São Paulo. Folha. Available at: https://www1.folha.uol.com.br/ cotidiano/2016/02/1736469-interpretes-de-surdosauxiliam-de-partos-a-formaturas-em-sao-paulo. shtml.

22. MONKEN, M. H. (2004, Aug. 4). Risco de assassinato $87 \%$ maior para negro. Folha. Available at: https://www1.folha.uol.com.br/folha/cotidiano/ult 95u98170.shtml.

23. MONTEIRO, J. L. (2000). Para compreender Labov. Petrópolis, RJ: Vozes.
24. MORENO-FERNANDEZ, F. (2009). Principios de sociolingüística y sociología del lenguaje. 4. ed. Barcelona: Ariel Letras.

25. PENTEADO, G. (2006, Nov. 18). Ser que só o branco pode trabalhar?, questiona empregada. Folha,. Available at: http://www1.folha.uol.com. br/folha/cotidiano/ult95u128374.shtml.

26. QUEIROZ, A. C. (2004). Politicamente Correto \& Direitos Humanos. Brasília: Secretaria Especial dos Direitos Humanos. Available at: http://www.dhnet. org.br/dados/cartilhas/a_pdf_dht/cartilha_politicame nte_correto.pdf.

27. STODŮLKOV, P. (2007). Changing Reception of political correctness. (Doctor's Thesis). Masaryk University in Brno. Brno (Czech Republic). Available at: https://is.muni.cz/th/146642/ff b a2/.

28. ZYLBERKAN, M. (2017, Dec. 7). Cliente de mercado em SP chamado de 'negro periférico' em briga na fila. Folha. Available at: http://www1.folha. uol.com.br/cotidiano/2017/12/1941302-cliente-demercado-em-sp-e-chamado-de-negro-perifericoem-briga-na-fila.shtml.

1 The concept of Valency was used, pioneeringly, by researchers of IUPERJ (University Research Institute of the State of Rio de Janeiro), today IESP (Institute of Social and Political Studies), from the State University of Rio de Janeiro (UERJ). Valency is applied to the media studies. Originally, the technique was developed for the analysis of press coverage on the presidential elections and the space dedicated to parties and candidates. Today, the technique can be applied to any topic of media coverage. In the methodology of the IUPERJ, valences were divided into positive, negative and neutral.

2 All emphasis in excerpts and quotations are added by the authors, except for foreign words. 